Journal of Nonformal Education and Community Empowerment

Volume 1 (2): 128-136, Desember 2017

Available at http://journal.unnes.ac.id/sju/index.php/jnfc

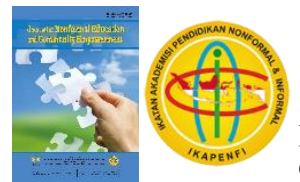

p-ISSN 2549-1539

e-ISSN $2579-4256$

\title{
Pembinaan Anak Rentan Tindak Kriminal melalui KUBE pada Anak Binaan PSMP Antasena Magelang
}

\author{
Bella Mulia Soviati ${ }^{凶}$, F. Fakhruddin, I. Ilyas \\ Pendidikan Luar Sekolah, Fakultas Illmu Pendidikan, Universitas Negeri Semarang
}

DOI: $10.15294 /$ pls.v1i2.14166

\section{Info Artikel}

Sejarah Artikel:

Diterima April 2017

Disetujui September 2017

Dipublikasikan Desember 2017

\section{Keywords:}

coaching; children vulnerable; criminal offense; planning; execution

\begin{abstract}
Abstrak
Penelitian ini bertujuan mengetahui proses perencanaan dan pelaksanaan pembinaan anak rentan tindak kriminal melalui usaha ekonomi produktif pada anak binaan PSMP Antasena Magelang beserta faktor penghambat kegiatan. Penelitian menggunakan pendekatan kualitatif. Subjek penelitian terdiri dari 3 peserta dan 3 pembina, sementara informan yaitu pengelola kegiatan dan pekerja sosial. Pengumpulan data dengan observasi, wawancara, dan dokumentasi. Keabsahan data menggunakan triangulasi sumber dan metode. Teknik analisis data dengan pengumpulan data, reduksi data, penyajian data, dan penarikan kesimpulan. Hasil penelitian menujukkan bahwa perencanaan dengan menentukan kegiatan, sasaran, dan anggaran dana yang disesuaikan dengan kebutuhan. Pelaksanaan berupa pemberian materi pembinaan berisi bimbingan sosial dan usaha ekonomi produktif. Kegiatan pembinaan menggunakan metode $70 \%$ praktik, selebihnya ceramah dan diskusi. Media pembinaan disesuaikan dengan kebutuhan. Faktor penghambat yaitu kurangnya minat anak, kurangnya antusias masyarakat dalam kegiatan, cuaca tidak menentu sebagai kendala dalam perkembangan jamur tiram, serta turunnya harga purna jual budidaya ikan lele sehingga modalnya berkurang.
\end{abstract}

\begin{abstract}
This study aims to determine the process of planning and implementation of child counseling vulnerable to criminal acts through productive economic efforts in the assisted children PSMP Antasena Magelang and inhibiting factors of activity. The study used a qualitative approach. Research subjects consisted of 3 participants and 3 coaches, while the informant was activity manager and social worker. Data collection with observation, interviews, and documentation. The validity of the data using source and method triangulation. Data analysis techniques with data collection, data reduction, data presentation, and conclusions. The results show that planning by determining activities, targets, and budget funds tailored to the needs. Implementation in the form of giving of guidance material containing social guidance and productive economic effort. Coaching activities use $70 \%$ practice methods, the rest of lectures and discussions. Media coaching tailored to the needs. Inhibiting factors are lack of interest of children, lack of enthusiasm of the community in activities, unpredictable weather as obstacles in the development of oyster mushrooms, as well as falling after-sale price of catfish cultivation so that the capital is reduced.
\end{abstract}

\footnotetext{
Alamat korespondensi:

E-mail: bella.soviati@yahoo.com
} 


\section{PENDAHULUAN}

Indonesia menyimpan kekayaan sumber daya alam yang cukup melimpah, dan juga memiliki modal sumber daya manusia yang cukup besar. Selain itu Indonesia yang merupakan salah satu negara berkembang, dimana segala macam perubahan diarahkan untuk mencapai pembangunan di segala bidang. Pembangunan sebagai proses menggambarkan adanya pengembangan, baik meliputi proses pertumbuhan ataupun perubahan dalam kehidupan bersama (sosial dan budaya). Hal demikian menurut Mulyono (2013) tidak lain merupakan gambaran umum dari masyarakat luas.

Seperti yang kita ketahui, selain menyimpan kekayaan sumber daya alam yang cukup melimpah, Indonesia juga memiliki modal sumber daya manusia yang cukup besar. Meningkatnya jumlah kelahiran setiap tahun membuat Indonesia tergolong menjadi negara berpenduduk tinggi di dunia. Peningkatan ini membawa dampak meningkatnya permasalahan kesejahteraan sosial di masyarakatnya, termasuk di antaranya adalah masalah kemiskinan. Ludoni et al. (2016:12) bahwa, "konsep kemiskinan bersifat multidimensional, sehingga untuk menyelesaikan masalah dan akar persoalan kemiskinan hendaknya juga meliputi seluruh aspek yang melekat pada kemiskinan".

Permasalahan kesejahteraan sosial seperti kemiskinan yang terjadi di Indonesia tidak hanya memberikan dampak negatif kepada orang dewasa saja, tetapi juga anak-anak. Dampak yang terjadi pada anak justru lebih berbahaya dari pada yang di timbulkan oleh orang dewasa. Karena dampak negatif oleh anak tersebut menyebabkan kerusakan jangka panjang. Bukan hal baru lagi jika melihat anakanak usia sekolah atau bahkan usia pra sekolah yang memiliki masalah kemiskinan. Semua itu mereka lakukan dengan alasan ekonomi. Anak yang putus sekolah maupun tidak mendapatkan pendidikan di bangku sekolah karena alasan perekonomian biasanya akan memilih hidup di jalanan dan hanya bisa memperoleh penghasilan dari mengemis, mengamen, asongan, pemulung, dan lain sebagainya. Namun, Pendidikan tetap sangat penting untuk anak sebagai generasi penerus bangsa. Hal ini sejalan dengan yang disampaikan Kurnia \& Budiartati (2017) bahwa pendidikan menjadi instrumen untuk mewujudkan masyarakat dan bangsa yang cerdas. Pendidikanlah yang harus dirancang dan diimplementasikan secara baik, yaitu adanya pendidikan yang maju pada masyarakat dan bangsa yang cerdas dalam kehidupannya.

Anak-anak layaknya mendapatkan kesempatan yang seluas-luasnya untuk dapat tumbuh dan berkembang secara optimal, baik fisik, mental, maupun sosial. Masa kanak-kanan merupakan periode pembentukan watak, kepribadian dan karakter diri seorang manusia. Terlebih lagi anak gampang terpengaruh oleh berbagai macam tindakan yang menimbulkan kerugian mental, fisik, sosial dalam berbagai bidang kehidupan. Tidak jarang anak yang memiliki permasalahan tersebut mengakibatkan dampak negatif seperti mendorong tindakantindakan kriminal hingga ke jalur hukum. Pengertian kriminal sendiri menurut Rusnani (2015:5), "segala macam bentuk tindakan dan perbuatan yang merugikan secara ekonomis dan psikologis yang melanggar hukum yang berlaku dalam Negara Indonesia serta norma-norma sosial dan agama".

Salah satu permasalahan anak yang krusial adalah anak yang melakukan tindak kriminal. Hal ini juga ditambah dengan munculnya tuntutan untuk menekankan pentinya fungsi sanksi dan tanggung jawab dari pelaku sebagaimana yang menjadi ciri dalam pendekatan hukum atau keadilan yang dalam hal ini hukuman yang diberikan adalah penjara. Hal demikian menunjukkan adanya suatu perbuatan atas pelanggaran-pelanggaran, sehingga di kalangan masyarakat khususnya dengan adanya kenakalan dapat menimbulkan kegelisahan yang nantinya dapat mempengaruhi kehidupan di keluarga maupun masyarakat sekitarnya. Para anak yang terlibat dalam pelanggaran norma hukum dan sosial dapat membahayakan dirinya sendiri dan orang lain. Pada kenyataannya masih banyak anak yang kurang beruntung dan mengalami berbagai masalah yang menyebabkan anak sebagai insan 
yang perlu mendapatkan perlindungan atas hakhak yang dimilikinya kehilangan hal tersebut. Salah satu permasalahan anak yang krusial adalah anak yang melakukan tindak kriminal.

Salah satu upaya yang dilakukan pemerintah dalam mensejahterakan kehidupan anak rentan tindak kriminal adalah melalui kegiatan pembinaan. Hal tersebut sesuai dengan pendapat Dewi (2016) bahwa pembinaan adalah usaha memperbaiki dan mempengaruhi tingkah laku seseorang agar memiliki kepribadian yang sehat, akhlak yang terpuji dan bertanggung jawab dalam menjalani kehidupannya. Kaitannya dengan permasalahan kesejahteraan anak, pemerintah menyediakan suatu lembaga sosial bagi anak rentan melakukan tindak kriminal untuk menanggulangi masalah kenakalan anak yang berkelanjutan ke hukum melalui Kelompok Usaha Bersama (KUBE) dengan program Kesejahteraan Sosial Anak, lembaga ini disebut sebagai panti.

Pelayanan dan pemenuhan kebutuhan di panti khusus anak dimaksud agar anak dapat hidup layak, belajar mandiri, dan dapat mengembangkan potensi-potensi yang dimiliki agar tidak mengulangi atau melakukan tindak penyimpang dan kejahatan. Pencegahan dan penanggulangan anak rentan tindak kriminal yang berada di luar panti yaitu dengan cara memberikan pelatihan-pelatihan. Dalam pelatihan ini yaitu mencakup life skill atau kecakapan hidup yang ditekankan pada keterampilan vokasional. Adanya pembinaan seperti pelatihan keterampilan sebagai bentuk penyaluran bakat anak yang rentan untuk melakukan tindak kriminal.

Panti Sosial Marsudi Putra (PSMP) "ANTASENA" Magelang merupakan salah satu unit pelaksana teknis Kementerian Sosial yang melaksanakan kegiatan operasional pelayanan sosial untuk mempersiapkan para anak tindak kriminal maupun anak rentan tindak kriminal agar dapat hidup secara mandiri dan menjalankan fungsi sosialnya secara wajar. Bentuk pembinaan yang diberikan meliputi pendekatan awal, penerimaan, assessmen dan perumusan masalah, bimbingan dan pelayanan sosial, resosialisasi, penyaluran dan pembinaan lanjut serta terminasi. Pembinaan yang diberikan oleh Panti Sosial Marsudi Putra "ANTASENA" Magelang ini meliputi pelayanan dalam panti dan pelayanan di luar panti. Adapun penelitian ini memfokuskan pada tahapan pelaksanaan rehabilitasi sosial dalam bentuk pembinaan anak di luar panti. Adanya pendidikan sistem panti yang diberikan khusus pada anak rentan melakukan tindak kriminal melalui pembinaan di luar panti dapat membentuk kemandirian anak dan mampu melaksanakan fungsi sosialnya secara wajar di dalam kehidupan masyarakat.

\section{METODE}

Berdasarkan pada pokok permasalahan penelitian yang dikaji, yaitu mengenai Pembinaan Anak Rentan Tindak Kriminal melalui KUBE pada anak binaan PSMP Antasena Magelang maka penelitian ini menggunakan pendekatan deskriptif kualitatif. Subjek penelitian berjumlah 8 orang terdiri dari 3 peserta dan 3 pembina. Sementara informan berjumlah 2 orang yaitu pengelola kegiatan dan pekerja sosial. Pengumpulan data dengan observasi, wawancara, dan dokumentasi. Fokus penelitian mencakup bentuk program, proses, dan faktor penghambat dalam pembinaan pada anak rentan tindak kriminal melalui KUBE dalam meningkatkan kemandirian anak binaan. Keabsahan data menggunakan triangulasi sumber dan metode. Teknik analisis data menggunakan model interaktif yang terdiri dari pengumpulan data, reduksi data, penyajian data, dan penarikan kesimpulan.

\section{HASIL DAN PEMBAHASAN \\ Perencanaan Pembinaan}

Tahapan perencanaan pembinaan untuk anak rentan tindak kriminal melalui Kelompok Usaha Bersama (KUBE) pada anak binaan PSMP Antasena yaitu mencakup; identifikasi kebutuhan, menetapkan tujuan, merancang bentuk kegiatan, menentukan waktu dan tempat, menentukan sarana dan prasarana, dan menentukan sumber dana. Menurut Fakhruddin (2011:55) perencanaan diartikan sebagai proses penentuan tujuan atau sasaran yang hendak 
dicapai atau disebut juga suatu rancangan, kerangka, pola fikir yang dijadikan dasar acuan pelaksanaan kedepannya dalam proses jangka panjang suatu program yang diharapkan. Tindakan atau kegiatan yang terorganisasi perlu dilakukan karena dua alas an menurut Sudjana (2000), yaitu mewujudkan kemajuan atau keberhasilan sesuai dengan yang diinginkan, dan supaya tidak terjadi hal-hal yang diharapkan.

Menurut Sutarto (2008) bahwa identifikasi merupakan bagian integral dari proses pengorganisasian dan perencanaan yang selanjutnya akan dijadikan sebagai panduan dalam penyusunan program atau pelaksanaan program. Identifikasi kebutuhan dari perencanaan kegiatan pembinaan adalah untuk mengetahui berbagai masalah atau kebutuhan program yang diinginkan oleh anak. Selain itu dapat mengetahui berbagai sumber yang dapat dimanfaatkan untuk pendukung pelaksanaan program dan mempermudah dalam menyusun rencana program yang dilaksanakan. Sehingga dalam penentuan jenis kegiatan untuk pembinaan akan disesuaikan dengan kondisi anak, lingkungan, dan potensi yang mendukung di sekitar wilayah yang akan diselenggarakan kegiatan pembinaan ini. Jadi identifikasi digunakan sebagai bahan acuan untuk menentukan bentuk kegiatan usaha ekonomi produktif kelompok usaha bersama yang tepat sesuai dengan potensi wilayah dan kemampuan anak binaan. Dari identifikasi kebutuhan dapat mengetahui berbagai masalah maupun kebutuhan yang sesuai dengan anak. Selain itu identifikasi kebutuhan digunakan sebagai dasar penyusunan rencana program kegiatan.

Hasil penelitian menunjukkan beberapa tenaga kesejahteraan sosial terkait dengan kelompok usaha bersama memiliki tujuan untuk meningkatkan keterampilan anak dalam melindungi permasalahan sosial dan pergaulan yang negativf, memberdayakan potensi anak untuk menciptakan kreatifitas dan peluang kerja, memberdayakan potensi anak untuk berperan menciptakan lapangan kerja serta meningkatkan usaha ekonomi produktif. Artinya tujuan dari pembinaan anak rentan tindak kriminal melalui kelompok usaha bersama adalah untuk memberikan kegiatan yang positif bagi anak agar terhindar dari perbuatan yang menyimpang. Dengan demikian di dalam kegiatan ini anak dapat mengembangkan potensinya untuk berperan aktif dalam melaksanakan peran sosialnya serta dapat meningkatkan perekonomian dalam memenuhi kebutuhan hidupnya. Sebagaimana yang diungkap Rifai (2008) bahwa tujuan merupakan pernyataan spesifik tentang apa yang ingin diperoleh, seberapa baik pernyataan harus diperoleh, dan diungkapkan dalam bentuk hasil yang dapat dikuantifikasikan (quantifiable) dan dapat diukur (meansurable).

Pemilihan bidang kegiatan diperoleh informan bahwa penetapan bentuk kegiatan sesuai dengan identifikasi kebutuhan dengan melihat beberapa hal untuk menjadi bahan pertimbangan, seperti melakukan analisis terhadap kegiatan yang pernah diterapkan sebelumnya serta melakukan evaluasi kegiatan kelompok usaha bersama yang pernah dilaksanakan. Kemudian kesepakatan dari beberapa pihak dan beberapa tahapan yang digunakan untuk merancang dan menetapkan bentuk kegiatan yang sesuai dengan kebutuhan anak. Sehingga akan mendapatkan kesimpulan apakah kegiatan tersebut sesuai dengan kebutuhan atau tidak, serta dapat menjadi pertimbangan dengan mencoba bentuk kegiatan di bidang lain atau melanjutkan bidang kegiatan yang sebelumnya. Bentuk kegiatan ini bervariasi sesuai dengan potensi lingkungan di wilayah yang digunakan sebagai tempat pembinaan. Kelompok usaha bersama ini mencakup bidang pertanian, peternakan dan perikanan. Hal demikian sejalan dengan Steele dalam Sudjana (2000) bahwa evaluation is the systematic process of judging the worth, desirability, effectiveness, or adequacy of something according to definitive criteria and puroses. Maksudnya adalah bahwa evaluasi program adalah proses penetapan secara sistematis tentang nilai, tujuan, efektivitas, dan kecocokan sesuatu yang dinilai sesuai dengan kriteria dan tujuan yang telah ditetapkan sebelumnya. Dengan didasarkan atas perbandingan secara hati-hati terhadap data 
yang diobservasi dengan menggunakan standar tertentu yang telah ditetapkan sebelumnya.

Dalam sebuah perencanaan kegiatan, perlu adanya sasaran dalam peserta kegiatan. Kelompok sasaran atau warga belajar yang akan menerima layanan program yang dirancang perlu ditetapkan dengan mempertimbangkan latar belakang, seperti pengalaman, pengetahuan, usia, dan kapasitas lainnya (Sutarto, 2008). Berdasarkan hasil wawancara dan pengamatan peneliti, sesuai dengan tujuan yang ditetapkan maka sasaran dalam program ini yaitu untuk anak yang masih berusia dibawah 18 (delapan belas) tahun tidak memiliki aktivitas, tidak sekolah, keluyuran dan meresahkan masyarakat, sehingga anak tersebut kemungkinan besar bisa melakukan tindak kriminal hingga jalur hukum. Anak dengan putus sekolah tentunya memiliki alasan tersendiri mengapa anak tersebut memutuskan untuk berhenti bersekolah. Hal tersebut sesuai dengan Veloso (2008) "these children, while not always 'street children' in the strict sense of the term, 2 spent most of their time roaming the streets, mostly because they needed the money they made there by peddling small merchandise, performing acrobatic tricks, or even sometimes mugging people". Bahwa anak-anak sementara tidak selalu "anak jalanan" dalam arti istilah yang seksama, sebagian besar mereka menggunakan waktu untuk berkeliaran di jalan-jalan, terutama karena mereka membutuhkan uang yang mereka buat dengan menjajakan barang dagangan kecil, melakukan trik akrobatik, atau bahkan kadang-kadang menjambret orang.

Setelah menentukan sasaran dalam kegiatan, maka tahap selanjutnya dalam melakukan perencanaan sebelum melaksanakan kegiatan yaitu penyusunan program. Dalam penyusunan program ini yaitu menentukan waktu, menentukan tempat, menentukan sarana dan prasarana serta menentukan sumber dana. Dari hasil penelitian yang diperoleh, penentuan alokasi waktu pelaksanaan pembinaan ini merupakan rencana agenda yang telah ditetapkan oleh PSMP Antasena. Sedangkan untuk tempat menyesuaikan kesepakatan dari pihak setiap lokasi yang digunakan sebagai pelaksanaan pembinaan. Selanjutnya tempat praktik dilaksanakan sesuai bidang yang telah di tentukan. Untuk budidaya jamur tiram, bertempat di kumbung jamur tiram milik tenaga kesejahteraan sosial Kecamatan Dukun. Kemudian untuk ternak kambing di kandang kambing yang lahannya milik salah satu anggota anak binaan, dan untuk budidaya ikan lele di lokasi kolam milik salah satu anggota anak binaan kelompok usaha bersama binaan PSMP Antasena. Sedangkan jangka waktu untuk pembinaan yaitu selama 6 (enam) bulan. Dalam enam bulan tersebut setiap bulannya diadakan pembinaan psikologi dari pekerja sosial untuk anak binaan. Berkaitan dengan pendekatan pekerja sosial sebagai suatu pemberian bantuan untuk meningkatkan keberlangsungan sosial pada anak binaan.

Tahap selanjutnya dalam menentukan tempat untuk pelaksanaan kegiatan ditentukan dari kesepakatan bersama pada saat musyawarah antara pihak PSMP Antasena dengan pendamping lapangan. Untuk pembinaan psikologi yang dilakukan satu bulan sekali dilaksanakan di rumah maupun salah satu anak binaan. Kemudian untuk menentukan sarana dan prasarana yang dibutuhkan dalam pelaksanaan pembinaan yaitu menyesuaikan bentuk kegiatan yang diterapkan dalam kelompok usaha bersama tersebut. Pengadaan sarana dan prasarana berupa tempat praktik kegiatan pembinaan melalui kelompok usaha besama tidak semua tempat dikenakan anggaran sewa, tergantung kesepakatan dari penentuan tempat di setiap wilayah.

Anggaran dana dalam pembinaan melalui KUBE berasal dari Daftar Isian Pelaksanaan Anggaran (DIPA) PSMP ANTASENA dengan Nomor DIPA. 027.04.2.426772/2016. Dana diberikan berjumlah Rp 6.250.00-, dalam bentuk rekening tabungan sebagai modal awal dan biaya pembelian perlengkapan praktik dalam kelompok usaha bersama sesuai dengan bidang yang telah ditetapkan. Alokasi anggaran dana dikelola oleh Kepala pengelola Advokasi sub bagian pembinaan luar panti PSMP ANTASENA sesuai wewenang yang kemudian diberikan kepada Tenaga Kesejahteraan Sosial 
Kecamatan untuk keperluan pelaksanaan program. Ini dilakukan dengan maksud agar laporan keuangan dapat terbukukan dengan baik dan rapi mengingat program ini diselenggarakan untuk beberapa wilayah. Serta untuk menghindari risiko keuangan di masa yang akan datang.

\section{Pelaksanaan Pembinaan}

Pelaksanaan kegiatan program Kegiatan

Kelompok Usaha Bersama (KUBE) dalam meningkatkan kemandirian anak rentan tindak kriminal pada anak binaan PSMP Antasena Magelang meliputi materi pembinaan, metode pembelajaran, hasil pembinaan, dan pembinaan lanjut. Materi yang digunakan dalam pembinaan sesuai dengan kompetensi pada instruktur atau pembimbing masing-masing kegiatan.

Diketahui bahwa penentuan materi diserahkan sepenuhnya pada pembimbing. Penyampaian materi menggunakan bahasa sederhana dan tidak memberatkan bagi anak. Selain itu dalam penyampaian materi bersamaan dengan praktek, sehingga memudahkan anak untuk memahami materi yang diberikan. Materi pembinaan disesuaikan dengan kegiatan dan tujuan pembinaan, serta bidang garapan yang ditetapkan. Dalam data penelitian yang diperoleh peneliti, bahwa kegiatan pembinaan terdapat dua pembelajaran dari PSMP Antasena memberikan pembelajaran psikologi untuk anak binaan. Pembinaan ini dilaksanakan oleh pekerja sosial PSMP Antasena dengan materi tentang bimbingan sosial, bimbingan spiritual, dan bimbingan mental. Proses hasil dari pembinaan sosial untuk anak binaan lebih kepada nilai, dimana yang terpenting anak tidak menjadi pelaku tindak kriminal. Materi yang diberikan pada anak bertujuan agar anak dapat menyalurkan skill melalui kegiatan keterampilan, memperoleh banyak pengetahuan agama, belajar selalu disiplin dalam berbagai kegiatan serta dapat menerapkan dalam kehidupan sehari-hari.

Pemberian materi yang bermanfaat tidak akan tersampaikan dengan baik apabila metode penyampaian tidak tepat. Sesuai dengan pengamatan dan wawancara yang dilakukan bahwa metode pembelajaran yang digunakan pada masing-masing bidang adalah sama, yaitu lebih menekankan metode $70 \%$ praktik dari pada ceramah dan diskusi. Untuk kegiatan kelompok usaha bersama lebih ke praktik langsung untuk mengetahui cara menjalankan program usaha sesuai dengan bidangnya masing-masing. Hal ini bertujuan agar semua anak dapat menguasai cara mengembangkan kelompok usaha bersamanya dan mendapatkan pengetahuan secara langsung sebagai bekal untuk meningkatkan perekonomian anak.

Penyampaian materi dengan menggunakan metode latihan praktik tentu tidak lepas dari penggunaan media pembinaan dan sarana prasarana. Berdasarkan hasil wawancara dan observasi, diperoleh hasil bahwa sarana dan prasarana sudah memadai. Media yang digunakan dalam pembinaan kelompok usaha bersama yaitu peralatan yang digunakan untuk praktik pertanian budidaya jamur tiram, praktik peternakan kambing, dan praktik budidaya ikan lele. Pendekatan emosional sangat berpengaruh dalam proses pembinaan dan minat anak dalam mengikuti pembinaan. Hal ini sesuai dengan Rifai (2008) yang menjelaskan bahwa media dalam arti luas adalah orang, material, ataupun peristiwa yang menciptakan kondisi yang memungkinkan partisipan memperoleh pengetahuan, keterampilan, dan sikap. Maksudnya pendidik, buku ajar, dan lingkungan belajar merupakan media.

Hasil dari pelaksanaan pembinaan melalui kelompok usaha bersama sangat berpengaruh terhadap keberhasilan sebuah program. Hasil dari pembinaan dapat dilihat dari penilaian terhadap anak oleh tenaga kesejahteraan kecamatan selaku pendamping lapangan dalam melaksanakan kegiatan tersebut. Penilaian tersebut berupa pengetahuan, sikap dan perilaku anak. Dari segi pengetahuan, dalam kegiatan ini dapat menambah pengetahuan anak binaan dalam hal mengelola usah, meningkatkan perekonomian melalui usaha serta pengetahuan tentang bagaimana berorganisasi. Selain itu mendapat pengetahuan mengenai sikap dan perilaku yang baik dalam 
kehidupan sehari-hari. Hal ini sangat membantu anak untuk mencegah terjadinya tindak menyimpang dari penyebab anak tersebut tidak memiliki aktivitas sehari-hari. Selain itu hasil pelaksanaan kegiatan ini dapat dilihat dari motivasi serta harapan anak untuk memperbaiki kehidupannya.

Hasil wawancara kepada anak binaan, bahwa mereka memiliki harapan yang sangat tinggi setelah mengikuti pembinaan. Hasil dari pembinaan ini dapat memotivasi anak untuk menjalankan kehidupannya dengan lebih baik. Terlebih dalam meningkatkan perekonomian kehidupannya. Terlihat dari antusias anak dan keinginan anak setelah mengikuti kegiatan ini mereka ingin mempunyai usaha untuk memperbaiki peekonomian mereka, bahkan salah satu dari anak binaan tersebut sudah memiliki usaha sendiri sebagai kegiatan sampingan selama mengikuti pembinaan.

Setelah terselenggarannya kegiatan, masih perlu adanya bimbingan lanjut. Mengingat umur anak yang masih di bawah 17 (tujuh belas) tahun masih perlu adanya bimbingan dan pendampingan lanjut agar anak tidak kembali memiliki pemikiran yang pasif untuk menjalankan kehidupannya. Selain memberikan pendampingan sesuai dengan batas waktu yang telah ditetapkan, PSMP Antasena juga masih menerapkan pendampingan lanjut setelah anak mengikuti pembinaan melalui kelompok usaha bersama. Anak masih diberikan pengarahan untuk perkembangan usaha selama kegiatan kelompok usaha bersama masih berjalan. Dari pembinaan lanjut juga melakukan pembinaan lanjut mengenai psikologi anak, guna mendapatkan penilaian terkait dengan perubahan karakter anak setelah mengikuti pembinaan.

Penghambat dalam proses pembinaan merupakan hal-hal yang menghambat dalam pelaksanaan proses pembelajaran tersebut. Sejumlah faktor psikologis yang mempengaruhi belajar salah satunya adalah minat, istilah lain dari minat adalah interests. Minat adalah kecenderungan untuk memperhatikan aktivitas secara bertahap. Setiap aktivitas yang diminati warga belajar akan terus diperhatikan dengan perasaan senang. Minat berpengaruh terhadap aktivitas belajar. Sebagaimana dikemukakan Siswanto (2013:38), "materi pembelajaran yang menarik minat lebih mudah dicerna dan diingat kembali".

\section{Faktor Penghambat}

Adapun faktor penghambat di dalam proses pembinaan melalui kegiatan KUBE yaitu pada saat awal memberikan motivasi dan penyuluhan kepada anak binaan di perlukan kerja keras dari petugas supaya mereka termotivasi dan mau mengikuti pembinaan hingga akhir. Sebagian besar di setiap kegiatan yang menjadi faktor penghambat dari proses pembinaan yaitu dari tingkat pendidikan, pemahaman, pengetahuan, keterampilan serta pengetahuan nilai-nilai dari setiap anak binaan berbeda, sehingga permasalahan yang dialami setiap individu anak binaan berbeda. Oleh karena itu pendampingan dari pekerja sosial memberikan bimbingan secara individu maupun kelompok sehingga permasalahan yang dialami setiap anak binaan dapat terselesaikan dengan baik. Untuk menanggulangi faktor pengambat yang bersumber dari anak, maka mereka memberikan sosialisasi dan memotivasi anak agar kembali antusias dan memiliki semangat untuk mengikuti kegiatan pembinaan melalui kelompok usaha bersama.

Adapun faktor lain yang menjadi penghambat adalah dari faktor lingkungan seperti masyarakat, cuaca maupun pemasarannya. Dari segi lingkungan masyarakat, masih ada sebagian masyarakat kurang menerima adanya usaha baru dari kegiatan tersebut. Hal ini terjadi di lingkungan masyarakat kelompok usaha bersama budidaya jamur tiram. Dalam menanggulangi faktor penghambat tersebut dengan cara memperkenalkan kepada masyarakat terkait dengan tujuan kegiatan serta produk hasil kegiatan anak, dengan harapan masyarakat ikut berpartisipasi dalam pemasaran hasil dari budidaya jamur tiram. Hasil dari usaha bersama budidaya jamur tiram sangat dipengaruhi oleh cuaca, karena dalam kegiatan ini perlu adanya kondisi cuaca yang sesuai untuk menjaga 
kelembapan udara karena hal ini mempengaruhi proses pertumbuhan jamur. Faktor dari kelompok usaha lain yaitu purna jual pada budidaya ikan lele yang sedang turun, sehingga tidak kembalinya modal usaha dari penghasilan yang diperoleh. Upaya penanggulangan faktor penghambat ini, pendamping lapangan beserta anak binaan masih melakukan kegiatan lanjut untuk budidaya ikan lele hingga harga pemasaran kembali naik.

\section{SIMPULAN}

Perencanaan pembinaan untuk anak rentan tindak kriminal melalui Kelompok Usaha Bersama (KUBE) pada anak binaan PSMP Antasena memiliki tahapan dalam perencanaan kegiatan yang mencakup identifikasi kebutuhan didasarkan pada peminatan dan potensi lingkungan, menetapkan tujuan berorientasi pada ekonomi produktif, menetapkan bentuk kegiatan didasarkan pada peminatan dan melihat potensi lingkungan, menentukan sasaran kegiatan disesuaikan dengan sasaran yang telah ditetapkan oleh pihak PSMP Antasena, menentukan waktu dan tempat didasarkan pada musyawarah oleh pendamping dan pihak PSMP Antasena, dan sumber dana sepenuhnya dari pihak PSMP Antasena dan dari peserta yang sifatnya sebagai penunjang.

Pelaksanaan kegiatan pembinaan mencakup materi yang disampaikan terkait dengan pembinaan meliputi bimbingan mental, bimbingan sosial, bimbingan spiritual, pemberian motivasi, serta materi usaha praktik. Metode pembelajaran lebih menekankan metode $70 \%$ praktik dari pada ceramah dan diskusi. Media yang digunakan yaitu peralatan yang digunakan untuk praktik sesuai dengan bidang garapan. Hasil dari pembinaan berupa pengetahuan yang diperoleh anak binaan serta perubahan pola pikir anak untuk meningkatkan perekonomian kehidupannya, dan pembinaan tindak lanjut berupa pengembangan usaha.

Faktor penghambat bersumber dari anak binaan adalah kurangnya antusias anak dalam mengikuti kegiatan tersebut, anak tidak memiliki pengalaman lain atau keahlian lain yang dimiliki selain dari tempat mereka melakukan pekerjaan sampingan. Segi lingkungan masih ada sebagian masyarakat kurang menerima adanya usaha baru dari kegiatan tersebut. Hasil dari usaha bersama sangat dipengaruhi oleh cuaca terutama pada budidaya jamur tiram, serta purna jual pada budidaya ikan lele yang sedang turun sehingga tidak cukup untuk mengembalikan modal usaha.

Kurangnya pendampingan pelatihanpelatihan yang berkelanjutan untuk pengembangan usaha karena bekal yang diberikan oleh pendamping hanya berupa pelatihan dasar. Sebaiknya panti memberikan pelatihan melalui peminatan kelompok kecil dalam kegiatan usaha, agar nantinya saat peserta ingin memiliki usaha secara mandiri memiliki bekal keterampilan yang lebih maju. Dapat dilakukannya pendampingan lapangan secara rutin sehingga kegiatan berjalan sesuai dengan tujuan secara maksimal. Jangka waktu pelaksanaan dijadwalkan terpisah dan fleksibel menyesuaikan anak binaan agar pelaksanaan pembinaan lebih tertata dan lebih terkondisikan.

\section{DAFTAR PUSTAKA}

Dewi, I. P. (2016). Program pembinaan dan pembelajaran bagi pecandu narkoba di yayasan rumah damai semarang. Universitas Negeri Semarang.

Fakhruddin, F. (2011). Evaluasi program pendidikan nonformal. Semarang: Unnes Press.

Kurnia, V., \& Budiartati, E. (2017). Kompetensi profesional instruktur dalam pencapaian hard skill peserta didik. Journal of Nonformal Education, 3(1), 21-27.

Ludoni, S., Noor, I., \& Hakim, L. (2016). Perencanaan program-program pengentasan kemiskinan dalam pencapaian target MDGs tahun 2015 di kota batu. REFORMASI, 6(1), 1-14.

Mulyono, S. E. (2013). Sosiologi pembangunan pendidikan. Semarang: Swadaya bekerjasama dengan Jurusan Pendidikan Luar Sekolah Fakultas Ilmu Pendidikan Universitas Negeri Semarang.

Rifai, A. (2008). Evaluasi pembelajaran. Semarang: Unnes Press.

Rusnani, R. (2015). Pengaruh kemiskinan terhadap meningkatnya kriminalitas di kabupaten sumenep. Performance: Bisnis \& Akuntansi, 5(1), 42-59.

Siswanto, S. (2013). Pengantar pengembangan 
kurikulum pelatihan pendidikan nonformal. Semarang: Unnes Press.

Sudjana, S. (2000). Manajemen program pendidikan. Bandung: falah Production.

Sutarto, J. (2008). Identifikasi kebutuhan dan sumber belajar pendidikan nonformal.
Semarang: Unnes Press.

Veloso, L. (2008). Universal citizen, unequal childhoods: Children's perspectives on rights and citizenship in brazil. LATIN AMERICAN PERSPECTIVES, 35(161), 45-59. 